\title{
BUILDING COALITIONS: Evaluating the Collaboration Process
}

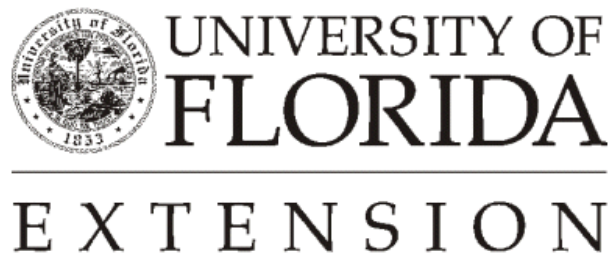

Institute of $\mathbf{F}_{\text {ood and }} \mathbf{A}_{\text {gricultural }} \mathbf{S}_{\text {ciences }}$ 
Evaluating and monitoring collaborative efforts are essential tasks if we are to be successful in coordinating programs for young people. Evaluation efforts become more manageable when approached from two different levels. These include: 1) evaluation of the collaboration process and 2) measuring the impact of programs for targeted audiences. This fact sheet focuses on evaluating the collaboration process.

An evaluation of the collaborative process can be pursued by studying several different potential outcomes.

\section{Potential Areas of Evaluation Quality}

- $\quad$ Training--What training has the group done for other youth professionals, coalition members or youth?

- Continuity--How long has the group been together? Is there still a desire to work together? What type of structure has been developed to assure the continuity of the collaboration, such as, officers, membership guidelines, memoranda of understanding?

- Involvement--How active are the group's members? How often do they meet? How much volunteer and professional time is being focused on a particular problem because of the collaboration?

\section{Comprehensiveness}

- What types of individuals and organizations are represented? Are these the right type of individuals to accomplish the work of the collaboration?

- Has there been an increase in the number of referrals between collaboration members? What has been the nature of these referrals?

- What types of data bases or directories have been created to facilitate the sharing of information and assistance related to youth issues?

\section{Access and Equity}

- Do all youth in the community have equal access to collaboration efforts?

- How do other non-collaborators obtain access to the information and services of the collaboration members? 


\section{Information and Advocacy}

- How has information been increased for parents, public, policy makers and youth?

- To what extent do member organizations promote each others' efforts, workshops and conferences?

- $\quad$ How is the group serving as an advocate for youth issues in the community?

\section{Cost-Effectiveness}

- Have existing funds been used more effectively? How?

- Has duplication of services been reduced or eliminated?

- How has the group been able to access new funds because of working together?

\section{Additional General Questions}

- What is the group doing that is really working well?

- What are the major problems the members of the group are facing?

- $\quad$ Are there unanticipated outcomes because of working together?

To explore the questions in the proposed areas of evaluation, many methodologies can be used. Some most common include:

- $\quad$ Surveys/Questionnaires

- Interviews

- $\quad$ Structured Observation

- $\quad$ Review of Records and Reports

- $\quad$ Focus Group Interviews

- Interaction Analysis 


\section{References}

Brinkerhoff, R.O., D. M. Brethower, T. Hluchyi and J.R. Nowakowski. Program Evaluation: A

Practitioner's Guide for Trainers and Educators. Boston: Kluwer-Nijhoff Publishing, 1985.

\section{Kagan, S.L., A.M. Rivera and F.L. Parker. Collaborations in Action: Reshaping Services to Young} Children and Their Families. Yale University, The Bush Center in Child Development and Social Policy, 1991.

\section{Author}

Richard W. Clark, Ph.D., The Ohio Center For Action on Coalitions, Assistant Professor, Extension Specialist, 4-H, Ohio Cooperative Extension Service, The Ohio State University.

\section{(C)1992 The Ohio State University}

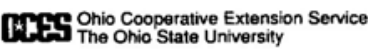

This series on Coalition Building was developed by The Ohio Center For Action on Coalition Development for Family and High Risk Youth, Richard Clark, Ph.D., Director. It has been adapted for County Extension Faculty in Florida to facilitate work with local and regional organizations and groups such as non-profits, cooperatives, county extension associations, and others that might benefit from a plan for working together to achieve support for mutual goals.

This document is FY499, Part 7 of the 16 part series adapted for use in Florida by Elizabeth B. Bolton, Professor, Community Development and Lisa Guion, Assistant Professor, Program Planning and Evaluation; Department of Family, Youth and Community Sciences, Florida Cooperative Extension Service, Institute of Food and Agricultural Sciences, University of Florida, Gainesville, 32611-0310.

Reprinted with permission March, 1997. Revised April, 2002.

The Institute of Food and Agricultural Sciences is an equal opportunity/affirmative action employer authorized to provide research, educational information and other services only to individuals and institutions that function without regard to race, color, sex, age, handicap, or national origin. For information on obtaining other extension publications, contact your county Cooperative Extension Service office.

Florida Cooperative Extension Service/Institute of Food and Agricultural Sciences/University of Florida/Christine Taylor Waddill, Dean 